\title{
The Ideas of Founding Fathers Choose The Presidential System As The Government System In Indonesia
}

\author{
Yusdiyanto $^{1}$ \\ \{yusdiyanto@gmail.com ${ }^{1}$ \}
}

Constitutional Law Departement, Faculty of Law, Universitas Lampung, Indonesia ${ }^{1}$

\begin{abstract}
Constitutional experts in Indonesia have explained that in every government structure sometimes adopts a presidential, parliamentary and sometimes mixed system. The government is pushing for amendments to the 1945 Constitution which initially aimed to reduce and rearrange the presidential government system. In practice, the amendment results raise several problems, namely the relationship between the executive and legislature tends to be "tangled", the two parties often do not understand their functions and authorities. This research method uses literature study in the field of constitutionality, with a historical approach and descriptive analytic research specifications. The results show that the Indonesian government system formulated by the founding fathers in the 1945 Constitution is a presidential system, with the following reasons: a) The agreement on a presidential system of government was formed from a process of debate in formulating the 1945 Constitution; b) There is an emphasis on power and responsibility in the hands of the President as head of state and head of government. c) The willingness to run the government can be carried out in a stable manner with the principle of separation of powers, and d) The President is elected based on the principle of deliberation / representation and is accountable to the assembly as the highest holder of the people. sovereignty to limit the power of the President without limitation (dictator).
\end{abstract}

Keywords: Founding Fathers, Presidential System, UUD 1945

\section{Introduction}

Historical experiences and debates of the founding fathers in establishing the state are an important part of the current and future the constitutional state system.

According to KC. Wheare, the birth of the constitution is:

"Constitutions, when they are framed and adopted, tend to reflect the dominant belief and interest, or some compromise between conflicting beliefs and interest, which are characteristic of the society at that time... A constitution is indeed the resultant of a parallelogram of forces-political, economic, and social-which operate at the time of it's adoption." "[1]

When the 1945 Constitution was compiled, the beliefs, values, and interests concerning an independent, united, and sovereign nation-state are the legal ideals (rechtsidee) of the Republic of Indonesia founders, which strongly influenced the value-function in the choice of decisions of the founding fathers and framers of the Indonesian constitution.

The constitional design in the form of a government system is interesting to be traced and researched more seriously. Bagir Manan said the importance of questioning the presidential government system was because it had influenced and even determined the government 
constitutional as the spearhead of the running of the state's wheels in all aspects of state life, especially in educating social welfare, as much as possible the prosperity of the people on the basis of social justice.[2]

The research based on the ideas of constitutional experts, namely: First, A.B. Kusuma said that the system of government according to the 1945 Constitution is using its own system, not adopting a presidential system like in the United States and it is different from a parliamentary system such as in Britain.[3] The opinion came from Soepomo's thoughts at the trial of the Investigator Preparatory Business for Indonesian Independence (BPUPKI) saying that the establishment of the Indonesian state was based on its own system. The system itself places the 5 (five) principles of Pancasila as the basis of the state and has the uniqueness of its own government system. The system itself is a system that does not imitate the governments of the United States, Britain, France, the Philippines or Brazil which uses the trias politica model as an implementation of the presidential, parliamentary or semi-presidential government systems.

Second, Tolchah Mansoer said that the system of government based on the 1945 Constitution is not entirely a presidential system of government. Because the presidential system means the head of government is the President, and on the other hand the President is not accountable to the House of Representatives. iT means the position of the President does not depend on the House of Representative.[4] The system of presidential government must be interpreted, because the cabinet is headed by the President and not his responsibility. So, the Indonesian executive must remain accountable, even though not to the DPR but accountable to the People's Consultative Assembly (MPR).[4]

In addition, the reason for this research is based on the practice of the government system development from Indonesian independence to the present. During the two decades of the constitutional (read: President Soekarno and Soeharto) the constitutional of a presidential government was full of executive-heavy, and the political format was not democratic, $[6]$ the product of the law has a conservative character with a positivistic instrumentalistic function,[7] law is manipulated in the interests of the authority and entrepreneurs because the President controls all lines of state power.[8] The 1945 Constitution is made sacred,[9] the concentration of the the presidential government system practice is focused on political stability in the context of national development. [9]

After the resignation of President Soeharto on 21 May 1999,[10] continued with the rejection of the People's Consultative Assembly (MPR) on speech of President B.J. Habibie, dismissal of President Abdurahman Wahid's from the MPR Special Session has pushed the balance of relations between the President and the DPR.[11] Dismissal of President Abdurrahman Wahid due to the political conflict between the President and the DPR in 2001.[11]

These various constitutional incidents have pushed for amendments to the 1945 Constitution which aim at reducing and rearranging the presidential government system, but the results of the amendments in practice have rise some problems. As the relationship between the executive and legislature tends to be "tangled", the two parties often do not understand the functions and authorities each other.[12] The DPR often enters the territory of government, and in the end the President cannot concentrate on running the government because of the intervention by the DPR. The form of intervention can be seen from when the DPR carries out its budgetary and supervisory functions.

From the viewpoint of constitutional and the development of government systems experts, it is important to carry out this research. For this reason, the research conducted was 
to explore the idea of the founding fathers choosing a presidential system as a system of government in Indonesia.

\section{Literature Review}

In determining the system of government in Indonesia, the founding fathers are based on the government system theory namely presidential system, a parliamentary system, and a mixed system. According to (Sarundajang, 2012), in this world, there is a system of government where is close relationship between executive power and parliament.[13] According to S.L. Witman and J.J Wuest the characteristics of a presidential system are based on the separation principles powers.[14] Meanwhile, the parliamentary government system is a government system where the parliament has an important role in government. [15] There is the idea of government system which can find parliamentary and presidential aspects or known as a mixed government system.[16] Thus, this research is based on the theory of presidential government systems, parliamentary systems and mixed government systems. Salah satu literatur yang melandasi teori ini yaitu buku yang ditulis oleh Sri Soemantri. Sri Soemantri said the 1945 Constitution produced by the founding fathers adopted a mixed government system, namely: a combination of a parliamentary government system and a presidential system of government.[5]

\section{Method}

The research used normative legal research. The legal research is based on literature and constitutional. The approach is historical approach.[17] The research specification is descriptive analysis. [18]

\section{Discussion}

\subsection{The Ideas of Founding Fathers}

The formulation of the Constitution starts from the formation of the Investigator Preparatory Business for Indonesian Independence (BPUPKI), [19] named Dokuritsu Zyunbi Tyoosakai based on Gunseikan Declaration Number 23, April 29, 1945.[4] As promised by the Japanese government, Prime Minister Kaiso, made in front of the Japanese parliament on September 7, 1945, BPUPKI was formed to grant Indonesian independence at a later date.[20] BPUPKI led by Radjiman Wedyodiningrat and deputy chairman of Hibangse Yosio and R.P. Soeroso. The promise of independence was inseparable from Japan's defeat in the Greater East Asian War.[21] There are two sessions of the BPUPKI, namely: 29 May-1 June 1945 and 1017 June 1945.[22] It is from the records of the constitution formulation.

The first day of May 29, 1945,[22] Muhammad Yamin conveyed the basic idea of representing Indonesia independence, namely the color and Indonesian thought in the state constitution. Representatives not only strengthen the customary law alliance in the lower state order, but also serve as guidelines for the current nation in compiling the central and upper state governance.[23] 
The composition of the central government is formed by the head of state, consisting of: a) deputy head of state, b) a ministry, and, c) the central parliamentary hall, which is divided into an assembly and a representative office for the people [23] According to Soesanto Tirtoprodjo, the idea of a government in accordance with the will of the people, it means that a People's Representative Body or Parliament is needed,[19] and the judiciary is one for the whole population and is free from the influence of government agencies.[3]

On the second day, May 30, 1945, according to Abd. Pratalykrama conveyed the principles of government is the head of state elected by the people and has a prime minister and a council of ministers. The People's Representative Body consists of the upper and lower assemblies whose members are elected by the people. [19]

On the third day of May 31, 1945, Soepomo broadly conveyed his ideas related to the intergralistic state (totalitarianism), is controlling power from other institutions over the executive branch. As a counterweight to the power of the head of state, a representative body of the people is needed, as Soepomo said:

"To ensure the leadership of the state, especially the head of state, and to continue the spirit with the Indonesian people in the composition of the Indonesian state government, a consultative body system must be established. The head of state will continue to associate with the Consultative Body so they will always know and feel the people's sense of justice. What will the form of the Consultative Body be, is one thing that we must investigate, but we should not use the individualism system".[19]

On the fourth day of June 1, 1945, Soekarno conveyed his ideas on the five basic principles proposed to become a philosifische gronslag or weltanschauung for an independent Indonesia, namely:

The people's representative bodies held there, according to the recipe of Fransche Revolutie. None other than what is called democracy there is just democracy; there is simply no sociale rechtvaardigheid, no social justice, no economische demokratieat all.[23]

Soekarno directly conveyed that the three foundations for an independent Indonesia were the basis for consensus, the basis for representation, and the basis for deliberation. The position of head of state, Soekarno explicitly rejected the monarchy model because monarchy was an erfelijkheid voorderstelt, it is from generation to generation. Soekarno firmly wanted a head of state to be elected.[23] To avoid the unlimited power of the head of state that leads to totaliarism.

Muhammad Yamin proposed the division of power into six parts, namely:

Power of the President, DPR, MPR, BPK, MA and DPA.[23] In his speech on 15 July 1945, Soepomo stated:

"The state government system is predominates the state power in the government, especially in the Head of State, concentration of power and responsibility in the hands of the Head of State".[23]

Soekarno conveyed the idea of a presidential system of government, but the President was not directly elected but through a people representatives body who appointed and dismissed the President.[24] Muhammad Hatta also gave the idea of a kinship state known as a "managing state" [25] which is based on the idea of people's sovereignty, mutual cooperation and joint efforts,[25] accountability for government power to the people,[25] state power limitation.[25]

Sukiman added that absolute stability in develop the country is carried out through its own system that is different from other systems of government.[26] The system itself means the head of state is not accountable to the House of Representatives, but the President is fully 
responsible to the MPR, which convenes every 5 (five) years, and at that time of course it will be clear whether the direction taken by the Government is approved or not by the MPR.[19]

At the trial, the founding fathers wanted the formation of the Republic of Indonesia based on the life style of the Indonesian people, namely the family system. To avoid imitating the western system, that time embraced presidential, parliamentary and quasi-parliamentary systems.

Table 1. The ideas of founding fathers is:

\begin{tabular}{|c|c|c|}
\hline No. & Proposer & Idea \\
\hline 1. & $\begin{array}{l}\text { Hoesin Djajadiningrat, } \\
\text { Soepomo, Soebardjo, } \\
\text { Singgih, Boentaran, } \\
\text { Soetadjo, } \\
\text { Sastromoeljono, } \\
\text { Soewandi, Maramis, dan } \\
\text { Soerachman. }\end{array}$ & $\begin{array}{l}\text { The Indonesian state is governed by a State } \\
\text { Leadership Council (DPN) consisting of three } \\
\text { people. The DPN is elected by the most votes } \\
\text { prominent people around Indonesia. }\end{array}$ \\
\hline 2. & Roseno & $\begin{array}{l}\text { The great leaders and regional leaders were } \\
\text { appointed by the Dai Nippon Army. Beside it is the } \\
\text { Parliament and the Advisory Council. }\end{array}$ \\
\hline 3. & Ny. Soenario & $\begin{array}{l}\text { The current form of civil servant government } \\
\text { continued with the head of state, his successor } \\
\text { Saikoo Sakikan. }\end{array}$ \\
\hline 4. & Poeroebojo & $\begin{array}{l}\text { The government is held by the Prime Minister (PM) } \\
\text { appointed by the Preparatory Body for Indonesian } \\
\text { Independence. Other Ministers are appointed by the } \\
\text { PM. }\end{array}$ \\
\hline 5. & Woejaningrat & The head of state was chosen by Tyuu Sangi In \\
\hline 6. & Soekiman & $\begin{array}{l}\text { Constitionale Monarchi is the title of Maharaja, but } \\
\text { the rank of the state is not hereditary. }\end{array}$ \\
\hline 7. & Soeroso & $\begin{array}{l}\text { The head of state is the Maharaja who holds an } \\
\text { office until the age of } 65 \text { years, but is not hereditary } \\
\text { and the people may also be dismissed before the age } \\
\text { of } 65 \text { years. The Supreme King was appointed by } \\
\text { Dai Nippon Teikoku. }\end{array}$ \\
\hline 8. & Ny. Ulfah Santoso & $\begin{array}{l}\text { Republic. Every Indonesian people can be elected as } \\
\text { head of state. }\end{array}$ \\
\hline 9. & Pratalykrama & $\begin{array}{l}\text { The Republic is chaired by a President assisted by } \\
\text { the PM who becomes chairman of the cabinet } \\
\text { assembly. }\end{array}$ \\
\hline 10. & Sanusi & Republic by the President \\
\hline 11. & Aris & $\begin{array}{l}\text { Republic, the President is formed by the young } \\
\text { President. }\end{array}$ \\
\hline 12. & Radjiman & $\begin{array}{l}\text { Republic, the President is assisted by the Vice } \\
\text { President }\end{array}$ \\
\hline 13. & A. Halim & $\begin{array}{l}\text { Republic (Jumhuriyah) with the President (Opening } \\
\text { Imam). }\end{array}$ \\
\hline
\end{tabular}




\section{S. Tirtoprodjo}

15. Parada Harahap

16. Tang Eng Hoa

17. Abdulkadir

18. Rooslan W. Koesono
Republic with the head of state elected for five years, at any time the BPR may terminate. Republic for a while (during the war)

Republic

Republic of the head of state stakeholders. Republic.

Source: A.B. Kusuma, Lahirnya Undang-Undang Dasar 1945, 2004, p. 181-183

Broadly speaking, it is known that the characteristics of the state government system are decided by the formulator of the 1945 Constitution. The explanation of the 1945 Constitution contains the state government system in the form of 9 (nine) main keys,[27] is as follows:[27]

1. Indonesia is a country based on law (rechststaat) and not based on mere power (machstaat).

2. Constitutional system. Government based on a constitutional system (basic law) is not absolutist (unlimited power).

3. The highest state power in the hands of the People's Consultative Assembly (Die Gesamte Staatgewalt liegt allein bei der Majelis). The sovereignty of the people is held by a body called the People's Consultative Assembly (MPR). As the incarnation of all Indonesian people (Vertretungs organ des Willens des Staatsvolkes). The Assembly sets the Constitution and sets out the Guidelines for State Policy. This Assembly appoints the Head of State (President) and Deputy Head of State (Vice President). This Assembly holds the highest power, while the President must carry out the direction of the state according to the outline set by the Assembly. The President is appointed by the Assembly shall submit and be responsible to the Assembly. He is the "mandate" of the Assembly and is obliged to carry out the decisions of the Assembly. The President is not "neben" but "untergeordnet" to the Assembly.

4. The President is the highest administrator of government under the Assembly. Under the People's Consultative Assembly, the President is the supreme administrator of government. In running the state government, power and responsibility are in the hands of the President (concentration of power and responsibility upon the President).

5. The President is not responsible to the House of Representatives (DPR), but beside the President is the DPR. The President must obtain the approval of the DPR to make a Law (Gezetsgebung) and to determine the state revenue and expenditure budget (Staatsbegroting). Therefore the President must work together with the DPR however the President is not accountable to the Council. It meas the position of the President does not depend on the Council even though the President is not accountable to the Council, so President's position does not depend on the Council.

6. The state minister is assistant to the President; the state minister is not responsible to the DPR. The President is appoints and dismisses state ministers. The ministers are not responsible to the DPR. Their position does not depend on the Council, but depends on the President. They are assistants to the President.

7. The power of the head of state is unlimited. Even though the Head of State is not responsible to the President, he is not a "dictator", it is mean the power is unlimited. It has been emphasized that he is responsible to the MPR. Unless, he has to pay close attention to the votes of the DPR.

And there are two main keys that are not given Roman numerals, namely: 
1. The position of the DPR is strong. DPR cannot be dissolved by the President (in contrast to the parliamentary system). In addition, all members of the DPR are also members of the MPR. Therefore, the DPR can always supervise the actions of the President and if the DPR considers the President has violated the law of the state, which has been determined by the MPR, the MPR can be invited to a special trial to ask the responsibility of President.

2. State ministers are not ordinary high-ranking officials. Although the position of state ministers depends on the President, they are not ordinary high-ranking officials. Because, it is the ministers who mainly exercise government power (pouvoir executif) in practice. As a department leader, the minister knows the ins and outs of his work environment. Based on this, the minister has a major influence on the president in determining state politics regarding his department. Indeed, it is mean the ministers are leaders of the state.

Based on Aulia A. Rahman's research results, the system of government produced by the 1945 constitution is the presidential system of government.[28] There are at least four main reasons became the reference points for the founding fathers and the framer of the constitution for choosing a presidential system of government, namely:

First, Indonesia needs strong, stable and effective leadership to ensure the continuity of the new proclaimation the existence of the Indonesian state. The nation's founders believed the strong and effective model of state leadership only created by choosing a presidential system of government. The President not only functions as the head of state but also the head of government. Second, due to theoretical reasons, namely reasons related to the ideals of the state (staatsidee), especially the ideals of the integralism state during the discussion of the 1945 Constitution at the BPUPKI session. The presidential system of government is believed to be very compatible with integralism. Third, at the beginning of fulfill the powers of the DPR, MPR and DPA. The choice of the presidential system is considered appropriate in fulfill this extraordinary authority. In addition, in the presidential system, the President can act more quickly in state problems solving during the transitional period. Fourth, it is a symbol of resistance to all forms of colonialism because the parliamentary system is considered as a product of colonization by the Indonesia founding fathers.[28]

From the idea of the founding fathers, when the 1945 Constitution was formulated, the character of the presidential government system was attached with the following characteristics: a) The President is a single executive who holds office for five years and can be extended again, b) Ministers are assistants who are appointed and responsible to the President , c) The MPR is determined as a locus of power that holds the supremacy of the highest state sovereignty, such Parliament in the parliamentary system, and d) State sovereignty is rests in the Indonesian people and held by the MPR as the manifestation of the entire people.

\subsection{Analysis of Choosing a Presidential System}

Based on the viewpoint of the founding fathers ideas, the Indonesian government system is presidential system of government as mention in the 1945 Constitution. It is reflected in the character and basic principles of presidential systems which are more dominant than parliamentary systems or mixed systems. The character of the presidential system is reflected in the articles and explanations in the 1945 Constitution as follows, namely:

a. The President holds government powers according to the Constitution.[29]

b. In undertake his duties, the President is assisted by one Vice President.[29] 
c. The President and the Vice President hold their position for five years, after that they can be re-elected.[29]

d. If the President dies, resigns or fails to carry out his duties during his term of office, the President is replaced by the Vice President until the expiry date.[29]

e. The President is assisted by state ministers.[29] The ministers are appointed and dismissed by the President.[29]

f. The President determines Government Regulations to carry out Laws properly and in a compelling crisis, the President has the right to establish Government Regulations in substitute of Laws.[29]

g. $\quad$ The President is not responsible to the DPR.[29]

h. The state minister is an assistant to the President and is not responsible to the DPR.[29]

i. The position of the DPR is strong and cannot be dissolved by the President.[29]

While the parliamentary principles are inherent in the 1945 Constitution before the amendment, namely:[29]

a. The President and Vice President are elected by the MPR with the most votes,

b. The MPR determines the Constitution, formulates the highest law (GBHN), the President submits and responsible to the MPR, the President is responsible to carry out the MPR decisions.

c. The President is the highest government administrator under the MPR.

d. Each law requires DPR approval.

e. If a draft of law does not get approval from the DPR, then the draft may not be put forward again at the DPR trial at that time.

From the character of the presidential and parliamentary government systems above along with the ideas of the founding fathers in formulating the 1945 Constitution, the choice is more competible to use a presidential government system rather than a parliamentary system or a mixed system. It is the origin of the idea of the founding fathers in determining the system of government based on the 1945 Constitution.

Based on the opinion of A. Hamid Attamimi has clearly stated that the 1945 Constitution adheres to a pure presidential system. The President positioned as state administrator who runs the state government.[30] The position of the DPR is in the representative institution and the MPR in the manisfestation of people's sovereignty.[30]

The position of the MPR is not a representative institution. The MPR is an institution with fully duties in the people sovereignty, so the MPR can be considered as the people themselves. Thus all the arrangements about the relationship between the President and the MPR which contained in the 1945 Constitution cannot be considered as a form of executive and legislative relations.

Bagir Manan also emphasized the system of government adopted by the 1945 Constitution is a presidential system with some reasons, but there are also differences in interpreting the government system contained in the 1945 Constitution, especially seeing the position of the MPR. According to Bagir Manan, the characteristics of the presidential system in the 1945 Constitution are: a) there is a certainty in the President term of office, namely five years, b) the President is not responsible to the DPR, and c) The President cannot dissolve by the DPR.[31]

In addition, the perceived characteristics of the parliamentary system in the 1945 Constitution are due to the position of the MPR as a legislative body, so the President's responsibility to the MPR is considered as the responsibility of executive power to the legislature.[31] The MPR institution is not a legislator because in the 1945 Constitution stipulates that laws are formed by the President with the approval of the DPR. 
Therefore, the MPR is not a legislative body, so the President's a responsibility to the MPR is not the responsibility to the legislative body or the cabinet's responsibility to parliament as contained in the parliamentary system. The MPR responsibility is a constitutional effort for checking and balancing, thus according to Bagir Manan there is no parliamentary feature adopted by the 1945 Constitution. So, the Indonesian government system is formulated by the founding fathers essentially a presidential system, not intended as a mixed government system.[32] Consider the materials used by the compilers of the 1945 Constitution, it is probably the structure and formulation of the President's power as the administrator of the government will be influenced by the structure and power of the President according to the United States Constitution.[32]

A similar opinion was expressed by Jimly Asshiddiqie, the government system of the Republic of Indonesia based on the 1945 Constitution, was actually intended as a presidential system. It has in the explanation of the 1945 Constitution and in the general sense which developed so far. Although, there are overlap provision between the presidential system and elements of the parliamentary system.[33]

This is the differences interpretations of constitutional law experts regarding the system of government adopted by the 1945 Constitution, as seen from the difference in understanding of the concept of the President's responsibility to the MPR or related to the position of the MPR in the constitutional structure. The Presidential system is idealized in the 1945 Constitution does not recognize the idea of the position of Prime Minister in the Indonesian government system based on the 1945 Constitution.

Thus, from the beginning, the founding father in formulating the 1945 Constitution had idealized the presidential government system. It is reflected in the form of governmental power based on the constitution held by a President assisted by one Vice President for five years and after that can be elected to the same position for only one term of office (Article 4 paragraphs 1 and 2 jo Article 7 UUD 1945). Even in carrying out his constitutional duties and obligations, the President is assisted by ministers who are appointed and dismissed by the President and responsible only to the President (Article 17 paragraphs 1 and 2 of the 1945 Constitution).

The presidential system has been embedded in the 1945 Constitution, namely in the President (and the Vice President) fixed executive term of office, if the President is unable to be replaced by the Vice President until the end of his term of office, the President is the head of state as well as the head of government, The president and ministers are not responsible to the House of Representatives.

\section{Conclusions}

The idea of formulating the 1945 Constitution by the founding fathers had been directed to use a presidential system of government, with the following reasons:

a) Agreement on a presidential system of government as established from the debate process in formulating the 1945 Constitution;

b) The constitutional state system emphasizes power and responsibility in the hands of the President as to the state and the head of government (concentration of power and responsibility upon the president); 
c) The presidential system of government is chosen with the desire for the administration of government can be carried out in a stable manner, with the principle adopted by separation power by rejecting the idea of trias politica, and

d) The President is elected based on the principle of deliberation / representation and he is responsible to the assembly as the supreme holder of the people's sovereignty to limit the power of the President indefinitely (dictator).

Since the beginning, the election of a presidential system by the founding father can be seen from the way it is formulated, a government system is more in line with the character of Indonesian people is a presidential system of government rather than a parliamentary system that has been practiced in Indonesia.

\section{References}

[1] K. C. Where, Modern Constitutions. Oxford: Oxford University Press, 1966.

[2] B. Manan, Membedah UUD 1945. Malang: Universitas Brawijaya Press (UB Press), 2012.

[3] A. B. Kusuma, Lahirnya UUD 1945. Jakarta: Fakultas Hukum Universitas Indonesia, 2009.

[4] M. T. Mansoer, Pembahasan Beberapa Aspek tentang Kekuasaan-Kekuasaan Eksekutif dan Legislatif Negara Indonesia. Jakarta: Paradnya Paramita, 1976.

[5] S. Soemantri, Tentang Lembaga-Lembaga Negara Menurut UUD 1945. Bandung: Citra Aditya Bhakti, 1993.

[6] Syamsudin Haris dan Riza Sih Budi, Menelaah Kembali Format Politik Orde Baru. Jakarta: Gramedia, 1995.

[7] Mahfud MD, Amandemen Konstitusi Menuju Reformasi Tata Negara,. Yogyakarta: UII Press, 1999.

[8] Denny Indrayana, "Negara Hukum Pasca-Soearto: Transisi Menuju Demokrasi vs. Korupsi,” $J$. Konstitusi, Mahkamah Konstitusi RI, vol. 1, no. 1, p. 103, 2004.

[9] Sulardi, Menuju Sistem Pemerintahan Presidensial Murni,. Malang: Setara Press, 2012.

[10] Aidul Fitriciada Azhari, UUD 1945 Sebagai Refolutiegrondwet. Yogyakarta: Jalasutra, 2011.

[11] Syamsudin Haris, Konflik Presiden-DPR dan Dilema Transaksi Demokrasi di Indonesia. Jakarta: Pustaka Utama Grafiti, 2007.

[12] S. Isra, "Hubungan Presiden dan DPR,” J. Konstitusi, vol. 10, no. 3, pp. 399-416, 2013.

[13] M. Anangkota, "KLASIFIKASI SISTEM PEMERINTAHAN (Perspektif Pemerintahan Modern Kekinian)," CosmoGov, vol. 3, no. 2, p. 148, Oct. 2017, doi: 10.24198/cosmogov.v3i2.14725.

[14] Z. R. Dewa, "Revitalisasi PKL di Kawasan Skywalk Cihampelkas Kota Bandung: Antara Kebijakan dan Kenyataan," Cosmogov J. Ilmu Pemerintah., vol. 05, no. 01, pp. 58-70, 2019, doi: 10.24198/cosmogov.v2i2.xxxxx.

[15] C. Elly Noviati Dosen Universitas Moch Sroedji Jember Ketua Pusat Kajian Konstitusi Jl Sriwijaya No, "Demokrasi dan Sistem Pemerintahan," May 2016. Accessed: Oct. 01, 2020. [Online]. Available: https://jurnalkonstitusi.mkri.id/index.php/jk/article/view/107.

[16] B. Inggris, "EKSEKUTIF Oleh I Nengah Suantra, S . H ., M . H .," 2004.

[17] P. M. Marzuki, Penelitian Hukum. Jakarta: Kencana Prenada Media Group, 2011.

[18] R. H. Soemitro, Metode Penelitian Hukum dan Jurumetri. Jakarta: Ghalia Indonesia, 1990.

[19] A.B. Kusuma, Lahirnya Undang-Undang Dasar 1945. Jakarta: Badan Penerbit Fakultas Hukum Universitas Indonesia, 2009.

[20] A.G. Pringgodigdo, Sejarah Pembentukan Undang-Undang Dasar Republik Indonesia. Jakarta: Majalah Hukum dan Masyarakat.

[21] Adnan Buyung Nasution, Aspirasi Pemerintahan Konstitusional di Indonesia: Studi SosioLegal atas Konstituante Republik Indonesia. Jakarta: Bumi Aksara, 1996.

[22] Joeniarto, Sejarah Ketatanegaraan Republik Indonesia. Jakarta: Bumi Aksara, 1996.

[23] M. Yamin, Naskah Persiapan Undang-Undang Dasar 1945. Jakarta: Jajasan Prapantja, 1959. 
[24] S. N. R. Indonesia, Risalah Sidang Badan Penyidik Usaha- usaha Persiapan Kemerdekaan Indonesia (BPUPKI) - Panitia Persiapan Kemerdekaan Indonesia (PPKI) 28 Mei 1945 - 22 Agustus 1945. Ed. III. Cet. 2. Jakarta: Sekretariat Negara RI, 1995.

[25] Armanto Riyanto, Negara Kekuasaan vs Negara Pengurus dalam Frans M. Parera dan T. Jakob Koerkerits, eds., Opini Masyarakat: Reformasi Kehidupan Bernegara. Jakarta: Penerbit Harian Kompas, 1999.

[26] "No Title." http://www.asianinfo.org/asianinfo/indonesia/pro-history.html (accessed Oct. 30, 2018).

[27] R. M. A. Kusuma, Sistem Pemerintahan (Pendiri Negara) vs Sistem Presidensiel (orde reformasi),. Jakarta: Fakultas Hukum Universitas Indonesia, 2011.

[28] Aulia Rahman, Sistem Pemerintahan Presidentil sebelum dan sesudah perubahan UUD 1945. Jakarta: Verbum Publishing, 2009.

[29] S. Lubis, M. Hutabarat, and M. R. Nasution, "Undang Undang Dasar 1945," vol. 4, no. 1, pp. 112, 2019, doi: 10.31227/osf.io/498dh.

[30] A. Hamid S. Attamimi, "Peranan keputusan presiden Republik Indonesia dalam penyelenggaraan pemerintahan negara suatu studi analisis mengenai keputusan presiden yang berfungsi pengaturan dalam kurun waktu Pelita I-Pelita IV," 1990, Accessed: Oct. 01, 2020. [Online]. Available: http://lib.ui.ac.id.

[31] B. M. dan K. Magnar, Pertumbuhan dan Perkembangan Konstitus Suatu Negara. Bandung: Mandar Maju, 1995.

[32] B. Manan, Lembaga Kepresidenan. Yogyakarta: Penerbit Gama Media, 1999.

[33] J. Asshiddiqie, Konstitusi dan Konstitusionalisme. Jakarta: Konstitusi Press, 2005. 